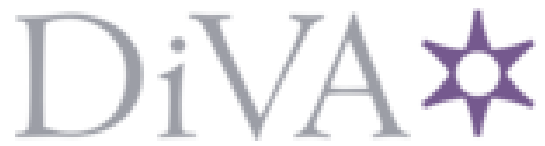

http://www.diva-portal.org

Postprint

This is the accepted version of a chapter published in Citizenship in Times of Turmoil? : Theory, Practice and Policy.

Citation for the original published chapter:

Mindus, P. (2019)

A Constitutional Eyesore After Brexit: EU Citizenship and British Nationality In: Edward Elgar (ed.), Citizenship in Times of Turmoil? : Theory, Practice and Policy (pp. 151-173). Cheltenham: Edward Elgar Publishing

N.B. When citing this work, cite the original published chapter.

Permanent link to this version:

http://urn.kb.se/resolve?urn=urn:nbn:se:uu:diva-393453 


\section{A constitutional eyesore after Brexit: EU citizenship and British nationality}

Patricia Mindus

\section{INTRODUCTION}

In this chapter, I explore what happens to British nationals after Brexit in relation to EU citizenship. More precisely, the central question is: What are the consequences that Brexit may entail for the regulation of nationality and migration in the UK, taking into consideration EU citizenship? No matter its shape, Brexit will need to imply changing the territorial scope of application of the EU Treatises. This will bring changes to citizenry: It is expected to shrink in size, change in composition and some parts of it will be left in potentially vulnerable positions. Here, I focus on the problems faced by British citizens who are resident in member states of the European Union after Brexit, but also British nationals living in the UK. Particular emphasis is laid on freedom of movement and rights relating to residence, but also on the loss of political rights that Brexit will entail. The aim is to allow the reader to understand some of the legal complexities affecting those who, on both sides of the UK border, have relied on free movement in making their life choices and what the effects of Brexit will be on the Union citizenry as a whole and what this may imply specifically for British citizens. The conclusion is that it looks likely that a tiered British citizenship will be the result, as well as a particularly worrisome constitutional eyesore that reduces some Union citizens to mere subjects of the European legal order.

A year back I argued that instead of engaging in shaky forecasting on where negotiations might lead, we ought to be clear about the cliff-hanger scenario: It is against this backdrop that progress (or regress) in negotiations is measured. It was premonitory to understand curtailment of rights and status, a topic I addressed in detail in the book European Citizenship After Brexit. Freedom 
of Movement and Rights of Residence. ${ }^{1}$ In the book, I made a methodological assumption about why we should engage in counterfactual legal analysis and not merely rely on more ordinary political forms of analysis.

As things stood then and as they stand in the moment of writing, the precise outcomes of negotiations cannot be foreseen. Therefore, I thought it wise to focus on determining what extra-negotiational resources are available, that is, what resources can we tap into regardless of what may happen in negotiations. I thus made the inquiry under the assumption of a non-negotiated withdrawal; or the assumption of a withdrawal treaty making no mention of free movement rights, which for the present purposes would amount to the same thing. Many have, of course, pointed out the unlikelihood of such a scenario. Now it looks much less unlikely given both the political setting and the time constraints than it did when I first wrote the book. Yet, the reason why I chose to operate under this assumption has nothing to do with the infelicitous choices of the current British administration. Rather, I made this choice because it is impossible to say if, and to what extent, negotiations succeed, or fail, unless we have a standard to test that success or failure against. ${ }^{2}$ Knowing what would have happened in counterfactual scenario of negotiations failing or not even occurring provides such a standard. In particular, I look at extra-negotiational legal resources available for freezing rights of people involved, asking questions such as: Can rights be frozen? Which rights? Whose rights? Under what conditions? For how long? To answer such questions, one needs to look at sources of international law and EU law, but also at lesser well-known guidelines and doctrinal instruments from state succession scenarios and the like. The conclusion is one of categorical change: some rights of (some of) the British citizens may be frozen, but Brexit will result in a generalized reduction of rights, a tiered British citizenship and probably also in the reduction of former Union citizens to mere subjects of the EU legal order. Summing these three features leads to a rather grim picture of what Brexit will mean for British citizens.

Also, it makes sense here to be careful about mechanical adoption of mainstream approaches. Merely transliterating what we (think we) know about citizenship might not do in order to do justice to the complexities involved. One reason for why this is that Brexit has an unprecedented character, not only because of the much-repeated reason that invoking Article 50 would be uncharted territory, which is unquestionably true. Also worth noticing

1 Mindus, Patricia. 2017. European Citizenship after Brexit: Freedom of Movement and Rights of Residence. Basingstoke: Palgrave Macmillan.

2 Other reasons have also been influential in choosing to work under the assumption of a non-negotiated withdrawal. The question of remedies in the absence of an agreement is relevant since there is no guarantee that any future agreement would have terms that are favourable to all affected groups, or would claim comprehensiveness. 
however, that it is not the first time in the history of European integration that the territorial scope of application of the Treatises changes. Previous modifications of territorial validity have included the following: French Comodores and the island of Mayotte (1975); Dutch New Guinea (1962); Algeria (1962); Greenland (1985); Saint Barthémely (2003). To be precise, more than half of what used to be member state territory have 'left' since the creation of the Communities. Yet, it may be argued that there is no relevant precedent. Algeria would probably constitute the closest precedent, if any were to be indicated. Yet, the events were such that the analogy does not hold. Not only because we are referring to a war of independence against France but also because from the end of the war in 1962 and 1975 when Algeria concluded a treaty with the EEC, the Treaties were nonetheless 'valid by implication' (sic!), even though Algerians lost the status of member state nationals for the purposes of Community law. However, the Community law in question was evidently a wholly different matter than EU law as it stands today. So, without engaging in predictions about what is likely to happen, what I want to do is to shed light on some problems that British citizens are likely to face on both sides of the border, that is, both British citizens resident in other Member states, also known as British second country nationals, and British citizens in the UK including their family members.

In order to explain why this matter is rather intricate, suffices to say we are looking at the simultaneous interaction of (at least) twenty-nine legal orders: twenty-eight member states of the European Union, and the law of the Union itself. To which we should also add the devolved constituencies in the UK, such as Scotland and Northern Ireland, and the international jurisdiction of the European Court of Human rights. The multiple interactions of rules from these origins are placing individuals before increasingly complex and counterintuitive sets of rules. It is fair to say that it forms a web, in which one would not want to be cast in whatsoever way. Let me start illustrating these intricacies by telling the tale of a European citizen. ${ }^{3}$

\section{A TALE OF AN EU CITIZEN}

I was not born an EU citizen. I did not become one until my country of nationality, which happens to be Sweden, accessed the European Union, back then called the European Communities. We might, therefore, say that I hereby joined my fellow-citizens, in 1995. Some three years earlier, at the signing of the Treaty of Maastricht, the status of European citizen had been created. Art.

\footnotetext{
3 On the history of EU citizenship see Maas, W. (2007) Creating European Citizens, Lanham: Rowman \& Littlefield Publishers.
} 
20 of that Treaty stated that 'every person holding the nationality of a Member State shall be a citizen of the Union'. A few years after that the European Court of Justice stressed that 'EU citizenship is destined to be the fundamental status of nationals of the MSs'. This is, by all standards, a rather avant-garde doctrine, from which however, it is worth recalling the Court has never departed.

From 1995, I thought of myself as having gained a special kind of freedom that translated for me, who was a 'second country national' living in another member state, into freedom from day-long queuing up, starting at dawn, to get a stamp on my permit of stay and thereby gain twelve months of respite from official scrutiny into my migration status. I later learnt that I had been granted a host of other rights too, including political rights, protections against bad administration, protection while in a third country and most crucially the right not to be discriminated against on the grounds on nationality. Like most other private citizens, I was, however, mostly glad to skip the queuing. Little did I know back then that rights were actually central to the whole endeavour. EU law is different from international law because it allows direct individual access to the justice system. This fact provides some insight into the very point of European citizenship: In the 'common provisions' in Title I, the parties to the Treaty are 'resolved to create a citizenship common to the nationals of their countries' and 'to strengthen rights of the nationals of their MSs through the introduction of a citizenship of the Union'. In other words, rights are a central aspect of Union citizenship. This is enough to understand why the claim made by many distinguished colleagues, like Adam Tomkins for one, according to which 'triggering Article 50 will not dilute or diminish anyone's statutory rights' is unconvincing. ${ }^{4}$ It is not true that having or not Union citizenship has no impact on the rights you hold as a UK citizen. Perhaps one should also add that the claim is particularly false given that we are speaking of UK citizenship, that is a nationality that does not automatically involve rights that are connected to many other nationalities, such as right to abode or right to vote. In the case of Brexit, exiting the Union means that all European citizens of British nationality risk losing rights associated with Union citizenship.

More precisely, the open list of rights associated with EU citizenship include the right to free movement within the Union, the right to vote and stand in elections both at the local and at the European level, the right to consular protection in a third country where one's home state is not represented, the right to petition the European Parliament, the right to appeal the ombudsman in cases of maladministration, to address institutions in all official languages, the

\footnotetext{
4 Adam Tomkins, Brexit, Democracy and the Rule of Law, https:// notesfromnorthbritain.wordpress.com/2016/11/05/brexit-democracy-and-the-rule-of -law/, 5 November 2016 ; last accessed 15 January 2019.
} 
right to good administration and the right to adhere to citizen's initiative. To this list one ought also to add jurisprudentially developed protections including the right to export entitlements tied to nationality to a host Member State ${ }^{5}$ and the right not to be burdened, or discriminated against for having exercised the freedom to move. ${ }^{6}$ These entitlements would therefore be lost together with the status of Union citizen.

In 1995, I was in my late teens and focused, as you can imagine, on much more futile things. With the blush of later gained wisdom, I recognise that, at that time, the freedom that I found personally, that is the freedom from queuing was good enough. Still today, it is the most cherished entitlement of Union citizens: freedom of movement, which includes the right of residence and the right to work. The so-called 'treaty rights' are exercised by millions in Europe today. The freedom of movement is one of four freedoms that grounds the European legal order and it originally protected perhaps foremost the cross-border white-collar workers in the Benelux heartlands, but it was a right that existed long before Union citizenship. Actually, with the notable exception of electoral rights, the rights associated with Union citizenship are mostly a systematisation of already recognized entitlements.

However, when freedom of movement was framed as a right of the European citizen with the Treaty of Maastricht in 1992, the innovative character laid not the right as such, but rather in the extension of the personal scope of a right that already existed. The entitlement was the same, but it now extended to a much broader category of individuals. This change in personal scope also implied that economic activities that have previously been central in the way freedom of movement had been interpreted was being relegated to a secondary role.

Yet, a question that is worth asking is whether, no matter how cherished it might be by the Union citizens themselves, free movement is a right of the European citizen? The answer is not as clear as one might first think. In fact, the ratio personae are both over- and under-inclusive. It is under-inclusive because it is not recognized unconditionally to Union citizens, since there are Union citizens that may not exercise the rights connected with it: those who risk becoming a burden on their host-state, those who lack health insurance and basic economic means. It is over-inclusive because the personal scope of the freedom of movement includes individuals who do not have EU citizenship. In fact, a number of Third Country Nationals are covered by the freedom of movement, either because their stay is short or because of their personal

5 See e.g., Case C-503/09, Lucy Stewart EU:C:2011:500.

6 See e.g., Case C-224/02, Pusa (Opinion of A.G. Jacobs) EU:C:2003:634; Case C-406/04, De Cuyper EU:C:2006:491). For an analysis of these, see F. Strumia (2013) 'Looking for Substance at the Boundaries: European Citizenship and Mutual Recognition of Belonging' 32 Yearbook of European Law 432-59, at 441-47. 
situation or qualification (e.g. blue card, intracorporate transfers, long-term residents, researchers, students).

In the Nineties when first created, it was not uncommon among scholars to celebrate European citizenship as the first post-national form of citizenship. As you will have noticed, it is a generally observed fact that the use of the suffix post to qualify a phenomenon is quite often a counsel of despair. So, it was in this case. Indeed, European citizenship is not a post-national status because it is precisely the nation states that are members of the European Union who hold the competence to determine who may count as a Union citizen: the criteria determining the access and loss of the status are in fact determined at the domestic level. This so-called derivative nature of European citizenship confers upon it the quality of a complementary status, different that is from dual citizenship status that is common in federal states for instance.

It is often said that the choice of giving European citizenship this derivative character was the easy way out in 1992. However, it was not the only option on the table. In the 70s, many had argued in favour of linking the status of European citizenship to the principle of soil, or ius soli, bestowing a birth-right status upon those born in the European Union. By the 90s, however, this looked as a politically unfeasible prospect. The Berlin Wall had fallen, migration from the global south was rising and asylum applications multiplied by tenfold with the wars and genocides on Europe's own borders. Making European citizenship derivative therefore seemed to be the easy option in order not to give up on the whole idea. The cost of this policy design choice is that different legal norms appear to be coexisting.

The fact that Member states control access to the status may seem straightforward, but it is also a source of intricacies: There are, as we have mentioned, twenty-eight access gates to the status. The choice of using mere lexical reference to Member state nationality laws in Article 20 of the Maastricht Treaty leaves the States in principle free to determine access criteria to the status.

A first consequence of this fact is that even though it is often claimed that all nationals of Member states are European citizens, it is more accurate to say that a Union citizen is a national of a Member state for the purposes of European law. Member states aiming to deprive of rights certain minority groups among their citizens have been able to engage in the inelegant practice of bringing this kind of unilateral declaration on the meaning of nationality for the purposes of EU law. This is most famously the case of the inhabitants of Färø islands who are Danish citizens but not European citizens, pursuant to such a unilateral declaration annexed to the Treatises. Yet another consequence is that, under EU Law, Member states may not decide who are to be considered as nationals of another Member state and therefore no additional criteria can be added to assess citizenship, such as the genuine link doctrine: Merely having the nationality of a Member state is sufficient to be recognized by the European legal 
order as a Second Country National. For as long as he lived, Fidel Castro could have applied for European citizenship without moving from Havana, because of his grandmother was Spanish, born in Spain, and the Spanish Nationality law recognized this fact as valid motive for recognition of Spanish citizenship by declaration. Before such a situation, the other member states would have been effectively deprived of the capacity of remedying the situation or forcing Spain not to apply its citizenship act.

This possibility of declaring some nationals of a Member state not nationals for the purposes of European law is a possibility that has not been fully explored in relation to Brexit. Yet notice that in the 'offer' presented to Parliament by the Secretary of State for the Home Department in the UK, in June $2017,{ }^{7}$ this possibility is not excluded. The document requires some careful reading as the information is tucked away at page 19 under the seemingly innocent heading 'glossary', but here we read that the UK reserves itself the possibility to regard its own nationals as not being nationals for the purposes of EU law. The text says that 'EU citizen' 'refers to any person who holds EU citizenship as established under Article 20 (1) of the Treaty on the Functioning of the European Union, save that for current purposes, persons who are EU citizens solely by way of their British nationality are excluded from the scope of this term'. Basically, this implies that 'save that for current purposes', i.e. in relation to status that individuals may hold after Brexit, the UK reserves itself the possibility of declaring some or all of its nationals outside the scope of jurisdiction of EU law, with effects on the possibilities of challenging the loss of EU citizenship and connected rights. While much discussion has centered on second country nationals in the UK and on Brits living in other EU countries, little mention has been made about this one group of some 60 million European citizens who are the UK nationals who have not exercised their treaty rights to freedom of movement around the European Union. Indeed, the British citizens who reside in the United Kingdom and have done so for most of their lives is the single most numerous group affected, yet the one who has commanded least attention.

Continuing the story of EU citizenship, nonetheless, it ought not slip from our attention, that those scholars who in the 90 s believed to be witnessing the creation of a post-national form of citizenship were, to be quite honest, not entirely wrong. European citizenship is indeed a non-exclusively national form of status civitatis. It is connected to entitlements that are supranational

7 The United Kingdom's Exit from the European Union Safeguarding the Position of EU Citizens Living in the UK and UK Nationals Living in the EU, June 2017 available at https://assets.publishing.service.gov.uk/government/uploads/system/uploads/ attachment_data/file/621848/60093_Cm9464_NSS_SDR_Web.pdf (last accessed 30 June 2018). 
and transnational, depending on whether they allow vertical connection with fellow-citizens above borders or if they allow horizontal activities that stretch beyond borders. In this meaning we can say that free movement and consular protection are transnational in character in so far as they are rights that stretch beyond borders, while electing the European Parliament or adhering to a Citizenship initiative are supranational in character in so far as they are rights that connect citizens above borders.

What makes European citizenship a non-exclusively national form of citizenship is the common principle that holds together all entitlements that one may enjoy as Union citizen, that is the freedom from discrimination on grounds of nationality. In European law, nationality is not considered a relevant criterion for ascribing to two individuals different legal positions, other things being equal, whereas differential treatment on grounds of nationality is a core feature of international law.

It is therefore fair to say that the principle of non-discrimination on the grounds of nationality is an atypical principle in the context of citizenship regulation. Traditionally, the very point of making the distinction between nationals and non-nationals is precisely to allow differential treatment. Citizenship, or status civitatis to use the legal term of art, is a status that is recognized only to those having some privileged relationship with the community. Originally, this relationship was conceived as a relationship of perpetual allegiance linking a territory's subjects to their ruler but, over the centuries, it came to be understood in national terms, even though formally the introduction of the principle of nationality in international law occurs rather late. In January 1851, Pasquale Stanislao Mancini, in his prolusion at the University in Turin, formulated the principle of nationality in the text entitled Del principio di nazionalità come fondamento del diritto delle genti, as the basis of the relationship of authority between the individual and state: The state becomes the institutional expression of the nation, providing the ideological reason for the Risorgimento movement in the unification of Italy. Over the last couple of centuries - and with significant difficulties in colonial settings - the prevailing idea was that differential treatment on grounds of nationality did not equate to discrimination. To the contrary, nationality was admittedly considered to offer justification, or good reason, to treat individuals differently. Here, European citizenship differs from traditional nationality quite significantly. But do notice also that it does so, not in its form or structure, but in its ideological underpinnings, that is in the way it which it is justified within the legal setting.

This second non-mainstream characteristic of Union citizenship may also be important in understanding Brexit. The European Union makes non-discrimination on grounds of nationality a point of its very own 'constitutional identity'. It is inscribed in the very nature of one of the four basic liberties that grounds the Union, free movement. Were it the case that certain union citizens would 
be deprived of rights merely on the ground that they hold a particular nationality this would violate the very basis of the constitutional identity of the Union. Indeed, the principle of non-discrimination on grounds of nationality is one of the basic principle of EU law. Lose that and EU law loses its specificity. Notice that until further notice all British citizens are also Union citizens. If they stop being Union citizens after Brexit, because the scope of validity of the Treatises is curtailed for instance not to cover the UK territories that would not jeopardize the Union's core commitment to non-discrimination on nationality grounds. However, if it were the case that British citizens would cease to enjoy rights connected to Union citizenship because they hold British citizenship this would violate the core commitment to non-discrimination. Were Brits stripped of their Union citizenship rights merely because they hold exclusively British nationality, they would be discriminated against on grounds of nationality. Precisely what EU law sets out to avoid. There is a risk that this will occur with Brexit as we shall explore in the last section.

To conclude we may say, first, that the entitlements of European citizenship include rights of a very different nature (including liberties, powers, protections etc.) and type (civil, political, social, etc.); having different grounds (systematisation, mutual recognition, federal vocation, etc.) and being different in character (transnational or supranational) and scope (all nationals of Member states, all residents, all having health insurance and not being a threat to public safety, etc.). The political bottom-line is not different from any other set of rights. As long as it continues to be based on a popular bargain among Member states rather than enjoying widespread popular support, the rights of the common citizenship remain endangered in the same way that citizenship rights everywhere remain contingent upon continued support from leaders and the public.

Here is where Brexit comes into the picture. For many European citizens who woke up estranged on 24 June 2016 after the Brexit referendum, it is precisely this status that they fear losing.

\section{NEW LEGAL UNCERTAINTIES}

No matter its shape, Brexit will need to imply changing the territorial scope of application of the EU Treatises. ${ }^{8}$ This will bring changes to citizenship, that is, the 'personal sphere of validity of the legal order'. ${ }^{9}$ The citizenry is

\footnotetext{
8 Articles 52 TEU and 355 TFEU which establish the territorial scope of application of the Treaties, merely list each Member state eo nomine.

9 Kelsen, H. (1945) General Theory of Law and State, Cambridge (Mass.): Harvard University Press.
} 
expected to shrink in size, change in composition and some parts of it will be left in potentially vulnerable positions. I lay particular emphasis on freedom of movement and rights relating to residence since they have been at the centre of much debate and because there are political reasons, due to the so-called hostile environment policy, that should lead us to stress also these aspects in particular. ${ }^{10}$ Will the negotiated solution take into consideration rights in the process of being acquired such as legal positions of those who are working towards a permanent right of residence? Or will there be a cut-off date for determining acquired rights? Will all those who had not matured the permanent right to reside by Brexit-day have their right to stay declared invalid retroactively? Will UK use its capacity to bring unilateral declarations on the scope of validity of its own nationality to the negotiation table?

The legal complexities affecting those who, on both sides of the UK border, have relied on free movement in making their life choices is likely to be significant, but uncertainties will also affect so-called static citizens, that is, those who have not made use of the freedom of movement yet who may have, for instance, family ties to people who have done so, and that therefore are concerned in a more indirect fashion. Many people are now worried about losing residence rights and being subjected to a different migration status, and this of course also includes the European citizens resident in the UK that are of indirect interest here since many British nationals have family ties to them, albeit I will not enter this issue in any detail here. ${ }^{11}$ Here, I focus mainly on the problems faced by British citizens resident in member states of the European Union $^{12}$ after Brexit and British nationals living in the UK. Another delimitation of the effects of Brexit on British citizenship concerns the constitutional effects that Brexit will entail for the UK. It has been submitted that 'to abolish many of these rights en bloc, with minimal or no parliamentary scrutiny, undermines fundamental rights, but is also undemocratic and detrimental to

10 Naturally, the so-called 'vested rights' for EU citizens in the United Kingdom and for UK citizens in the EU cover a much broader subject matter than freedom of movement, including, e.g., social policy, non-discrimination law, and fundamental rights. Here we will deal foremost with free movement since the Brexit debate centred on migration. Even narrowing down the topic in this way the numerous difficulties that emerge promise an increased workload ahead.

11 See P. Mindus, European Citizenship After Brexit, Palgrave, 2017, chapter 2.

12 In 2016 there were approx. 690,000 UK citizens currently living in EU member states: See Eurostat (2016), 'Population on 1 January by five-year age group, sex and citizenship (migr_pop1ctz)' (http://ec.europa.eu/eurostat/web/population-demography -migration-projections/population-data/database/). The majority of these UK citizens reside in Spain, but a significant number are living in Ireland, Germany, the Netherlands, Italy, Belgium, and Sweden. 
the parliamentary sovereignty'. ${ }^{13}$ However, this inquiry will not treat these constitutional implications of the problem.

All things considered, it is fair to say that there will be much insecurity for all the categories involved, on both sides of the emerging border. The reduction of rights will affect not only British citizens but also SCN in the UK and their family members. Here are some cases:

Consider, for example, Timothy who is a ballet dancer in Paris. Would he be granted a Blue Card to continue the profession or would he be considered self-employed subjected to the intricate French regulations? How about his flatmate Christopher who works as an assistant on a project at a local university: Does he now fall within the remit of the European Directive on third country national researchers? ${ }^{14}$ What happens to Margaret, who is one of the 106,610 claiming UK pension in Spain? ${ }^{15}$ She sold her house in Cambridgeshire and retired on the Costa Brava. Will the European rules that guarantee the upgrading of her British pension no longer apply? Sally, an unpaid trainee at a multinational in Amsterdam, is offered the opportunity to work in a subsidiary in Slovakia: Can she accept and bring her husband with her? Would she discover she needed to fall within the remit of the intra-corporate transfers? Or within the remit of the European Directive on Students? ${ }^{16}$ How about Ryan who catwalks for the autumn collection in Milan: Would he have some limited equality rights under the single permit directive (2011/98/EU) or would he be considered a seasonal worker, in which case his residence would be subject to a strict time limit? ${ }^{17}$ Bryce, who teaches English in Krakow, will have a hard time bringing over his mother Allie who needs care: She would count as third country national family member and member states have stricter domestic regulations on family reunion than the regime applicable to Union citizens. Cillian, originally from Belfast, has been living

13 Douglas-Scott, S. (2015) 'Constitutional Implications of a UK Exit from the EU: Some Questions that Really Must be Asked', U.K. Const. L. Blog, (17 April 2015), available at https:/ukconstitutionallaw.org/2015/04/17/sionaidh-douglas-scott -constitutional-implications-of-a-uk-exit-from-the-eu-some-questions-that-really-must -be-asked/ (last accessed 1 January 2019).

14 EU Directive on third country national researchers 2005/71 EC, 12/10/2005 OJ L 289, 18.6.2009, 17-29.

15 Data from Department for Work and Pensions: http://tabulation-tool.dwp.gov .uk/100pc/sp/cccountry/cat/ccgor/a_carate_r_cccountry_c_cat_p_ccgor_claimants _living_abroad_aug15.html (last accessed 30 June 2018).

${ }_{16}$ Directive 2004/114/EC on the conditions of admission of TCN for the purposes of studies, pupil exchange, unremunerated training or voluntary service.

17 See the Directive 2014/36/EU of the European Parliament and of the Council of 26 February 2014 on the conditions of entry and stay of third-country nationals for the purpose of employment as seasonal workers. 
in Madrid for over a decade working as a software developer. Frustrated by not having his say in the referendum, he considers naturalizing to fool his country's intention of stripping him of his rights as a European citizen. Would he be able to pass the language proficiency test (DELE) and another one on his knowledge of Spain (CCSE) that Spain has imposed since October 2015? Would he need to renounce his original nationality to naturalize in Spain? Kylie from Gibraltar, has run a bed and breakfast in Barcelona since 2010: Will she be required to apply for the European status of long-term residency for third country nationals or can she keep the more advantageous permanent residency? Dexter is part of an avant-garde theatre group in Amsterdam but he lacks any serious command of Dutch: Can he naturalize or will he be hindered by the 'integration test' the Netherlands has imposed since 2007 ? Abigail, who is a part-time tourist guide in Stockholm, is anxious about her studies in biology: Would they let her continue working? Will she now need to pay the 15,000-euro tuition fees for non-EU nationals? Annabel came to Rome as a student. She has a relationship with an older, married man and does not want to go home. Her American cousin overstayed her visa in Australia. Can she just stay put? Maybe her lover will file for divorce? Maybe not. If she stays put, can she be detained? According to the EU's Return Directive (2008/115/EC), post-Brexit British citizens who do not, or no longer, have a right to stay would have to be expelled, by force if they did not go voluntarily. To facilitate departure, they could be detained for up to six months, or up to eighteen months if there were complications with their removal. Now, consider self-sufficient Ulrike from Germany, who has been married to Peter, and living in Sussex for almost two decades. She now discovers that, for the Home Office, her ability to use the NHS - which she has regularly used most notably when giving birth to their children - does not count as 'comprehensive sickness insurance' so therefore she has never built up a right of residence. ${ }^{18}$ She was just physically present in the United Kingdom, they tell her. But she knows she could get a European health insurance card from her home country and even get it backdated. There is a reciprocal healthcare arrangement with Germany. The Home Office, though, requires her to sign a declaration if she wants to use this option: She must declare that she has no intention of staying

18 According to Colin Yeo, tens of thousands of persons are in this situation. Watch Migrants' Rights Network, available at https:/www.youtube.com/watch?v $=$ Doi3KYfkbp8\&spfreload=5 (last accessed 30 June 2018). Generally on the situation of Germans in the UK: Mulder, J. (2016) 'The Personal Implications of the Referendum Results for (German) EU Citizens Living in the UK', German Law Journal - Brexit Supplement, available at https://static1.squarespace.com/static/ 56330ad3e4b0733dcc0c8495/t/5776e5e6579fb3bc18d93eab/1467409894916/15+PDF _Vol_17_Brexit+_Mulder.pdf. 
permanently in the United Kingdom: What is she going to tell her husband? Or take Olivier, a self-employed psychologist in Bristol, who gets married to his girlfriend from Portugal: Will he be able to bring his spouse to the United Kingdom or will he need to prove, in accordance with the more restrictive British policy, that he earns $£ 18,600$ pa, which he, as almost half of the UK population, does not?

These hard cases show the many dimensions involved for British citizens and their family members after Brexit. It may be relevant to address such hard cases in the withdrawal treaty and/or treaty over the future relations with the United Kingdom so as to curb future litigation and limit the number of administrative errors that are likely to rise, given the manifest inability of the Home Office and the associated agencies to deal effectively with the current situation, even before Brexit occurs.

Let us now ask, on the basis of the methodological assumption outlined and defended in section 1, what happens after Brexit for UK citizens? Prima facie, this is the situation:

While European citizens having the nationality of any of the other twenty-eight Member states currently living in the UK will stay Union citizens and will be able to recover full rights upon return to the 'territory of the Union' and keep non-territorial rights associated with EU citizenship (for example, consular protection), a very different scenario awaits British citizens having no other member state nationality to rely on. British citizens will be deprived of EU citizenship rights in a non-negotiated Brexit scenario.

A non-negotiated Brexit would indeed transform all Union citizens of exclusively British nationality in third country nationals (TCNs). They will lose rights associated with freedom of movement and residence, ${ }^{19}$ yet some of the

19 Freedom of movement and residence is not an entitlement strictly linked to Union citizenship: its ratio personae is both over- and under-inclusive. It is not recognized unconditionally to Union citizens (as underscored by Case C-333/13 Dano EU:C: 2014:2358) and a number of third country nationals are covered by acquis in relation to freedom of movement. Third country nationals holding a valid residence permit or visa have the right to move freely within the Schengen area for up to three months within a six-month period, the rights in relation to taking up residence for a period exceeding three months in another member state is covered by specific legal instruments, depending on their status, and subject to conditions in national legislation (e.g. blue card, intracorporate transfers, long-term residents, researchers, students). See E. Spaventa, (2008) 'Seeing the Woods Despite the Trees? On the Scope of Union Citizenship and Its Constitutional Effects' 45 Common Market Law Review 13; García Andrade, P. (2014) Privileged Third-Country Nationals and Their Right to Free Movement and Residence to and in the EU: Questions of Status and Competence in Elspeth Guild, Cristina Gortázar Rotaeche, Dora Kostakopoulou (eds) The Reconceptualization of European Union Citizenship, Brill, Leiden 2014, $111 \mathrm{ff}$. 
British citizens abroad will still be protected by EU law because of specific circumstances relating to their employment and their family status. ${ }^{20}$ Moreover, those who would not be protected in their residence status by these instruments would still see the European Convention of Human Rights step in and protect the residence rights of those lawfully residing in the territories covered by EU law at the moment of independence. British nationals living elsewhere in the Union could indeed rely on the Kurić doctrine. ${ }^{21}$ But British nationals as such can no longer invoke civis europaeus sum. This implies losing other rights such as, for instance, consular protection by another Member state.

Also, worth noticing is that while many European citizens resident in the UK will not automatically be subjected to restricted political rights because of Brexit since twenty-two-member states allow their nationals to vote for the European Parliament also when they reside in a non-EU state, British citizens will however lose the political rights associated with EU citizenship. They will lose voting rights for the elections of the European Parliament and the right to adhere to European citizens' initiatives; and those British nationals living in other member states will keep the right to vote in local elections only where the member states allow third country nationals to vote (e.g. Sweden) without reciprocal arrangements (e.g. Portugal). Given the number of member states that reserve elections exclusively for nationals, this means in practice that British citizens living in the Union will lose local political citizenship in sixteen member states.

British citizens in other Member states will also lose these rights, but they will not - differently from fellow-nationals in the UK - lose rights associated with EU citizenship the personal scope of which is over-inclusive in respect of having the nationality in a Member state. British citizens in the Union would retain these rights also as third country nationals. Some rights associated with European citizenship are indeed recognized to all residents, and not to all having the nationality of a Member state. Such as the right to petition Parliament and the Ombudsman (Article 24) from the Maastricht Treaty, the right, introduced with the Nice Charter in 2000, to access documents from

20 Residence rights for all other categories than family members of Union citizens and primary carers of minor Union citizens resident in the EU cannot be upheld on the basis of European law. P. Mindus, European Citizenship After Brexit, Palgrave 2017, chapter 5 .

21 Application No. 26828/06, 26 June 2012, Kurić v Slovenia. The punchline of Kurić is that 'once you have lawfully established residency, you keep the rights of residence, even if the legal status of either your home State or your Host State changes and, as a result of this change, your new nationality status alone would no longer give you a right to residence': J. Vidmar, (2013) 'The Scottish Independence Referendum in an International Context', Canadian Yearbook of International Law, vol. 51, p. 28. 
European Parliament, Council and Commission (Art. 42) and the right to good administration (Art. 41). Neither would UK nationals lose the right, introduced with the Treaty of Amsterdam in 1997, to address the European Union in any official language and to receive a reply in that same language (Art. 24), since other member states use English as official language. Notice also that some of these entitlements do provide voice and as such are perhaps well classified as political rights, yet do not have the incisively that voting rights have.

In the event of failed negotiations, Union citizens would lose their right to live in the United Kingdom based on the Treaties and EEA nationals in the United Kingdom will no longer benefit from the rights contained in the Citizens Directive 2004/38/EC, implemented into British domestic law via the Immigration (EEA) Regulations from 2006. The United Kingdom could apply its national immigration laws to all EEA citizens, that would require (merely) repealing s 7(1) of the Immigration Act 1988, which provides that leave to enter or remain in the United Kingdom under the Immigration Act 1971 is not required by a person who is entitled to enter the United Kingdom by virtue of EU rights. Also, prospective EU migrants, that is, those who wish to migrate to the United Kingdom after Brexit would be affected. ${ }^{22}$ Any arrangements that allow EU citizens to continue to live and work in the United Kingdom would have to be negotiated. This in practice implies that failed negotiations will impact the lives of all British citizens, resident in the UK, who have family relations to nationals of any member state, which is not an insignificant number of British citizens.

Add to this scenario that British citizens may have family ties to people who, being EU citizens, would be transformed simply into 'foreigners' and subjected to the full force of British immigration law in the event of an agreement-less exit, yet might not have matured residence rights in the UK so would therefore be in absence of 'acquired rights'. It is not unlikely that a negotiated solution, by the way, would show more consideration for EU citizens already living in the UK than EU citizens not doing so. An intriguing case would be that of 'former second country nationals', that is, EU citizens resident in the EU who are family members of British nationals, wishing to join these members in the United Kingdom. They could, of course, claim family rights, but not in virtue of the more protective EU law. So, they would indeed witness a reduction of rights in this regard. Most certainly, they would be excluded from the protection offered within the ambit of Union law: The European Court of Justice has qualified the 'genuine substance' doctrine of Ruiz Zambrano pointing out

22 Peers, S. (2016) 'Migration, Internal Security and the UK's EU Membership', The Political Quarterly, Volume 87, Issue 2, pp. 247-53, April-June 2016. 
that the mere desire to keep a family together does not constitute ground for accommodating claims by third country nationals. ${ }^{23}$

To conclude, some of the severe effects of Brexit on British nationals concerns migration policy, because the European Union has partially harmonised immigration laws: Article 77 TFEU provides that the Union is competent to adopt rules relating to the absence of internal border controls, the management of external borders and short stay visa policy; Article 79 TFEU provides that the Union may adopt rules relating to the conditions of entry and residence, the definition of the rights of third country nationals residing legally, illegal immigration and unauthorised residence, and combating human trafficking. Harmonisation in these areas means that the laws applicable to British citizens in the Union would be a mixture of common European standards and the residual domestic immigration laws of each of the member states. Basically, it entails increased scrutiny of British nationals at EU borders. The Union could impose visa requirements, including for short-term trips and holidays, since the United Kingdom is not a party to the earlier treaty on Regulations governing the Movement of Persons between Member States of the Council of Europe from 1957 that abolished visa requirements between European states. ${ }^{24}$ It also means that British citizens, both those who are now resident in the UK and those who are resident elsewhere, and who wish to reside for longer periods in a member state of the European Union would be subject to the EU rules on immigration including quotas and EU-preference rules on labour migration.

All in all, we are looking at a significant reduction of rights, all over the spectrum, from political rights, to right to reside, right to family life and many other entitlements as well. While member states, it seems, are in principle free to revoke the status of Union citizen, former member states are however not unbounded in stripping Union citizens of their acquired territorial rights. The European Convention of Human Rights is likely to step in and protect the residence rights of those lawfully residing in the territories covered by EU law at the moment of independence, which may help protect the residence status of some family members of British citizens. The supranational rights of Union citizens being subjected to a massive lapse of status would, however, be much harder to vindicate.

23 See Joint Cases 356/11 and 357/11, O, S EU:C:2012:776, §52; Case C-87/12, Ymeraga EU:C:2013:291, §38; Also see Case C-86/12, Alokpa EU:C:2013:645.

24 Peers, S. (2016) 'Migration, Internal Security and the UK's EU Membership', The Political Quarterly, Volume 87, Issue 2, pp. 247-53, April-June 2016. 


\section{AN AUTOMATIC AND COLLECTIVE LOSS OF CITIZENSHIP}

It was long supposed that the only way to lose European citizenship for a European citizen was by losing member state nationality. Already, the Resolution on the draft Treaty establishing the European Union from 14 February 1984, stressed that European citizenship 'may not be (...) forfeited (...) independently of nationality of a member state'. ${ }^{25}$ With Brexit, the nationality of the former member state is not lost, but Union citizenship would be. So, Brexit proves that there is another way to lose 'the fundamental status': Ex lege automatic loss due to the exiting of a member state. Indirectly, Article 50 adds a ground for loss of Union citizenship. This ground for loss finds its mirror image in the acquisition of Union citizenship ex lege for states acceding to the Union according to Article 49 TFEU. The argument, in keeping with traditional theories of statehood, is that any mutation to the legal status of territory can thus naturally be expected to generate effects for the citizenship status of (at least some) inhabitants.

With Brexit, therefore, we are witnessing a form of involuntary $\operatorname{loss}^{26}$ of citizenship en masse, ex lege, imposed on those EU citizens that have British nationality. Ex lege means that this is bound to occur by the automatic workings of the law, not by individual renunciation. It is important here to remember that Article 15 of the Universal Declaration on Human Rights states that everyone has the right to a nationality, which may not be withdrawn arbitrarily. Leading principles on loss of nationality that may be found in binding documents like the articles 5-9 of the 1961 Convention on the Reduction of Statelessness or the 1997 European Convention on Nationality, however, would not apply since Brexit would not cause statelessness. Indeed, the people who would see their EU citizenship disappear would stay British citizens. But the abovementioned article 15 does not only refer to loss of citizenship as such but also to it

25 European Parliament, OJ C 77/53, 19 March 1984.

26 A terminological remark is needed: There are many expressions relating to loss of status civitatis: loss, quasi-loss (or ex tunc declaration of invalidity), deprivation, lapse, withdrawal, renunciation. Deprivation or withdrawal is usually an administrative measure by the competent authorities whilst lapse or ex lege loss happens automatically by operation of the law. Renunciation is voluntary. See Glossary Eudo-citizenship, available at http://eudo-citizenship.eu/databases/citizenship-glossary (last accessed 30 June 2018). Weis, Paul. (1979). Nationality and Statelessness in International Law. Netherlands: Springer. De Groot, G.-R. (2015) Survey on the Rules on Loss of Nationality in International Treatises and Case Law, in S. Carrera Nuñez, G.-R. De Groot, European Citizenship at the Crossroads. The Role of the European Union on Loss and Acquisition of Nationality, Oisterwijk: Wolf Legal Publishers, 2015, p. 10. 
being prohibited if arbitrary. ${ }^{27}$ And although the Universal Declaration is not a binding instrument, the forbiddance of arbitrary deprivation is repeated in other treatises and instruments. 'Deprivation', which domestically is an act of the administration, in this setting, covers ex lege loss of nationality and here the UNDHR is clearly reminiscent of the Decree of Adolf Hitler of 25 November 1941 that determined loss ex lege of status for Jewish citizens of Germany.

An intriguing issue is whether the loss of Union citizenship entailed by Brexit might demonstrate arbitrary features in its being unchallengeable. The application of loss provisions must be possible to challenge in court, but in this scenario, it is unclear whether the principle would imply letting British citizens challenge the loss provision before an English court, before courts in member states where they are residing, or before the European Court of Justice. As I have shown elsewhere, ${ }^{28}$ there is a quite limited possibility that the European Court of Justice might be involved, and for several reasons such a solution may be highly problematic for political reasons: The Court might need to rely on its Rottman doctrine. ${ }^{29}$ However, the worrisome aspect of this is that under international law, a provision that causes people to lose citizenship needs to be challengeable. Were this the case the Brexit loss provision would comply with international law requirement on being challengeable. While it seems likely that some rights associated with Union citizenship could be upheld if deprivation of these was challenged, it is less clear if loss of the status as such could be challenged, let alone if it could be frozen for the British citizens concerned.

27 For a general overview, UN Human Rights Council (12009), Human Rights and Arbitrary Deprivation of Nationality: Report of the Secretary-General, 14 December, $\mathrm{A} / \mathrm{HRC} / 13 / 34$

28 Mindus, P. European Citizenship After Brexit, Palgrave 2017, chapter 6.

29 In the Rottman case, the European Court of Justice concluded that a citizen of the Union who is faced with a decision withdrawing his [citizenship], and placing him (...) in a position capable of causing him to lose the status conferred by Article 17 EC [Article $20 \mathrm{TFEU}$ ] and the rights attaching thereto falls, by reason of its nature and its consequences, within the ambit of European Union law. (Case C-135/08 Janko Rottmann v Freistaat Bayern [2010] ECR nyp, § 42). Comparing the situation of Mr. Rottmann with that of Ms. Kaur (16 Case C-192/99 The Queen v Secretary of State for the Home Department, ex parte: Manjit Kaur [2001] ECR I-01237), the denial of access to nationality would not constitute a problem, but the very fact that Rottmann once had the status of Union citizen, which he lost, was crucial in order to fall within the scope of European law. The Rottman doctrine is applicable not only to cases of deprivation when a fraud is discovered and statelessness is the result, but also in other cases of deprivation, even if no statelessness is caused but the EU citizenship could be lost: G.-R. De Groot, Survey on the Rules on Loss of Nationality in International Treatises and Case Law, in S. Carrera Nuñez, G.-R. De Groot, European Citizenship at the Crossroads. The Role of the European Union on Loss and Acquisition of Nationality, Oisterwijk: Wolf Legal Publishers, 2015, p. 35. 
If the loss provision cannot be challenged, it would not comply with the requirement of international law and would fall into the category of 'arbitrary loss of citizenship', which is prohibited by a range of international instruments. If this would be the case it would, to say the least, be quite embarrassing. But on the other hand, if it could be challenged, before which court would that be? National court? Before the ECJ? And if you could challenge the loss of European citizenship that Brexit causes before the ECJ, would it not go against Art. 50? Would exiting not lose its effet utile if the court can rule that loss of EU citizenship is illegitimate?

Once we acknowledge that British citizens will lose European citizenship, with Brexit comes a constitutional dilemma: Must we say that the transnational rights that constitute EU citizenship cannot be erased at will by the exiting state? So, rights exercised under EU law will outlast the legal provisions that created them. Or, we must say that the rights of Union citizens may very well be suppressed if a Member State decides to exit? Union citizenship really is not the 'fundamental status' the European Court of Justice speaks of: it is not even protective of pretty basic things: such as staying to live where you built your life or joining family members. On this scenario, it really is not a right, but more like a conditional gift. If rights are maintained, would we want to sacrifice the will of the people to exit on the altar of individual rights? Or, would we prefer to sacrifice the rights of EU citizens on the altar of democratic self-determination of (only) one-member state of the Union? For some, imposing EU rights protection on the people of a Member State who just voted to leave the Union would be nothing less than a coup d'état. ${ }^{30}$ I shall not, as abovementioned, venture into the constitutional aspects of this issue, but just point out that we are dealing with a collective automatic loss of EU citizenship for all those holding exclusively British citizenship. This loss, however, does not create statelessness and it is likely to be tolerated under public international law. It is also important to signal the fact that the loss is involuntary and indicates the modality of loss, not the will of the status holder. Legally, the loss of citizenship is involuntary insofar as it is not a case of (individual) renunciation. In the case of Brexit, one may also make the political claim that it is involuntary because $48 \%$ expressed their will to remain European citizens; certain territories voted massively in favour of staying and the UK citizens

30 Dawson, M., Augenstein, D., 'After Brexit: Time for a further decoupling of European and national citizenship?' VerfBlog, 14 July 2016, available at http:// verfassungsblog.de/brexit-decoupling-european-national-citizenship/ (last accessed 30 June 2018). 
residing abroad were disenfranchised, even though they were among the most affected. $^{31}$

No matter which reading one chooses, it stands clear that Brexit is expected to cause an automatic en masse loss of European citizenship for individuals, residing on both sides of the border of the United Kingdom. The people who will be affected are the British citizens, no matter whether 'static' or 'mobile', that have exclusively British nationality, with no other EU member state nationality to rely on. This effectively creates two consequences:

A first consequence is a tiered British nationality: Part of the British citizenry will have access to EU citizenship rights via their second nationality where they do hold nationality in a member state of the European Union. ${ }^{32}$ The rest of the British citizenry will not. This effectively introduces a difference in protection within the formerly identical citizenry. It is also important to remember that not only will they not have access to EU citizenship, but most crucially they will effectively be deprived thereof. There is a significant difference between never having had access to particular status, and having been deprived of it.

A second consequence is that EU citizenship will be truncated by Brexit. This ought to interest all Union citizens regardless of whether they feel affected by Brexit or not; and regardless of their nationality. How reasonable is it, from the point of view of the European citizens, that a part of the citizenry, deliberating by majority vote in a consultative election, rejects the common citizenship, when this common citizenship provides political rights to influence the political life not only of the part, but of the whole?

\section{A CONSTITUTIONAL EYESORE}

The negotiations are creating EU citizens of a lesser kind. According to the draft 'transitional arrangements in the withdrawal agreement' between the European Union and the United Kingdom, Union law is to be binding on the UK during the transition period, but not as it relates to the European citizen rights of UK nationals. These shall cease on Exit Day, under the draft agree-

31 The UK supreme court refused the permission to appeal on the grounds of purely domestic law, leaving all EU citizens of UK nationality residing in other member states disenfranchised in the referendum: UKSC 2016/0105.

32 This is especially the case in Northern Ireland, which already has half a million Irish passport holders. Many people in the United Kingdom are Irish citizens by descent from parents or grandparents born in Northern Ireland or the Republic of Ireland. In some cases, in order to establish their citizenship, they will first need to enter their names on the register of foreign births. But for many people asserting their Irish citizenship, which has been dormant is simply a matter of applying for an Irish passport. 
ment. Not only will British citizens lose Union citizenship in ways that are profoundly challenging for the legitimacy of the legal membership in any political association, but during the transition they will lose it without gaining the freedom from living under the rule in question. In the hubris of yearning for a cake to have and to eat, lost will be both the cake and the plate.

As we have seen, Brexit will entail limitations to many rights that British citizens currently enjoy under EU law. Some of these rights will be 'frozen' for some British citizens, most notably those living in other member states. Yet among the rights that will not be 'saved' we find the political rights, such as voting for the European Parliament and participating in a European Citizen Initiative. When we read in the draft agreement on the transition that EU law would be valid but not as it relates to the European citizen rights of UK nationals, this in practice translates as British citizens will be a disenfranchised part of the EU citizenry.

The stripping of citizenship and disenfranchisement of British EU citizens will occur in virtue of the fact that (some of) their fellow-nationals (and others who were allowed to vote) voted for Brexit in a consultative referendum three years earlier. Depriving British citizens of Union citizenship on mere grounds of nationality is deeply problematic for all parties involved. The principle of non-discrimination on grounds of nationality is, as mentioned, a basic principle of EU law. Were EU law to be valid on UK territories after exit while disenfranchising UK nationals in the EU polity at the same time, it would indeed imply that British citizens are being stripped of their political rights pursuant to the fact that they exclusively hold British nationality. This would, in turn, challenge an EU 'core constitutional commitment' to the principle of non-discrimination, a general principle of EU law. Had it been the case that EU law would cease to be valid on UK territories (i.e., the scope of validity of the Treatises curtailed), this unconstitutional consequence would not follow. But if EU law continues to be binding but former Union citizens of exclusively British nationality are being disenfranchised in the polity they once belonged to but keep on being subjected to, it is a different story altogether. In other words, if they are being stripped of their political rights pursuant to the fact that they hold only British nationality, are they not being discriminated against on grounds of nationality? Was it not precisely what EU law ought to have prohibited? Would it not frustrate the very nature of the principle of non-discrimination on the grounds of nationality?

Some Union citizens, indeed, will lose their 'fundamental status' (to speak with the ECJ) in 2019. These lesser kinds of EU citizens are those who are not EU citizens in virtue of living under EU law, as all the others are: The legal grounds of EU citizenship is the validity of the Treatises so in the UK the Treatises would still be valid but not for the purposes of saving the rights of Union citizens. Yet Brits will still be living under EU law: Under the transition 
period British former EU citizens would live under EU law even on UK territories. EU law will continue to be binding for all other purposes except the purposes that grant them their fundamental status vis-à-vis that very legal order. Ironically, these British citizens will also lose their right to signing European Citizen Initiatives. Living under a rule to which one is denied voice in shaping the formation of its collective decision making is nothing less than arbitrary. It is the $\mathrm{ABC}$ of constitutional democracy. This basic premise is not upheld in the current situation. Making millions of Britons live under EU law yet stripped of their status as fellow citizens is a quite remarkable constitutional eyesore. 